Robert B. Forbes MD FRCPC, Gail E. Vandewalker MD

\title{
Comparison of two and ten per cent rectal methohexitone for in- duction of anaesthesia in children
}

\begin{abstract}
Plasma methohexitone concentrations were determined in 30 children, aged one to six years, who received $25 \mathrm{mg} \cdot \mathrm{kg}^{-1}$ rectal methohexitone as either a two per cent or ten per cent solution for induction of anaesthesia. Venous blood samples were obrained $15,30,45$ and 120 minutes following drug administration. Twenty-six of 30 children were asleep within fifteen minutes. Mean plasma methohexitore concentrations were 5.39, 4.42, 3.40 and $1.54 \mu \mathrm{g} \cdot \mathrm{ml}^{-1}$ at 15. 30.45 and 120 minutes following administration of two per cent methohexitone. Use of the ten per cent solution resulted in mean plasma methohexitone concentrations of $3.81,3.12,2.31$ and 1.07 $\mu \mathrm{g} \cdot \mathrm{ml}^{-1}$ at the same time intervals. Plasma methohexitone concentrations were significantly higher at 15, 30 and 45 minutes following administration of two per cent methohexitone, when compared to the ten per cent solution.
\end{abstract}

Rectal administration of methohexitone is an effective technique for the induction of anaesthesia in young children and several doses and concentrations of the drug have been used. ${ }^{1-6}$ However, when methohexitone is administered as a ten per cent solution in the usual clinical doses approximately 15 per cent of patients do not fall asleep. ${ }^{3-6}$ This unpredictability may occur because of variation in the absorption or systemic availability of the orug. Many factors affect absorption and distribution of rectally administered medications including drug formulation, site of absorption within the rectum, and concentration and volume of the solution administered..$^{7.8}$

\section{Key words}

ANAESTHESIA: paediatric; PHARMACOKINETICS: methohexitone; PREMEDICATION, RECTAL: methohexitone.

From the Department of Anesthesia, University of Iowa College of Medicine, Iowa City, lowa, 52242.

Presented at the 1986 American Society of Anesthesiologists Annual Meeting, Las Vegas, Nevada.

Address correspondence to: $\mathrm{Dr}$. Forbes.
Laishley et al. reported that rectal administration of 15 $\mathrm{mg} \cdot \mathrm{kg}^{-1}$ one per cent methohexitone, and $25 \mathrm{mg} \cdot \mathrm{kg}^{-1}$ ten per cent methohexitone, were equally effective for the induction of anaesthesia in children, but that use of 15 $\mathrm{mg} \cdot \mathrm{kg}^{-1}$ of a ten per cent solution resulted in a significantly higher failure rate. ${ }^{9}$ In addition, damage to the rectal mucosa has been reportcd following administration of ten per cent methohexitone in mice. ${ }^{10.11}$ Because of the potential problems of failed inductions and mucosal injury that may occur with the use of ten per cent methohexitone, a more dilute solution of rectal methohexitone may be desirable for induction of anaesthesia in children. Therefore, the purpose of this investigation was to compare plasma methohexitone concentration, time to the onset of sleep and post-anaesthesia recovery in children following rectal acministration of $25 \mathrm{mg} \mathrm{kg}^{-1}$ methohexitone, as either a two or ten per cent solution.

\section{Methods}

Thirty ASA physical status I children, aged one to six years, scheduled for elective surgery were studied after obtaining informed parental consent to the institutionally approved protocol. All patients were unpremedicated and accompanied to the preoperative holding area by their parents. They were randomly assigned to receive either the two or ten per cent methohexitone solution. The solutions were prepared by dissolving $500 \mathrm{mg}$ sodium methohexitone in 5 or $25 \mathrm{ml}$ of sterile water to form the ten and two per cent solutions, respectively. Each child received a total dose of $25 \mathrm{mg} \cdot \mathrm{kg}^{-1}$.

The drug was instilled through a soft, plastic catheter inserted approximately $3 \mathrm{~cm}$ into the rectum, while the patient was held and comforted by a parent. The time from administration of the drug until the onset of sleep was recorded. For purposes of this investigation sleep was defined as loss of consciousness, unresponsiveness to verbal stimuli, and absence of voluntary movement when unstimulated.

Children were then transported to the operating room, intravenous cannulation performed and anaesthesia con- 
tinued with nitrous oxide and halothane in oxygen, except in a single patient with a family history of malignant hyperthermia in whom nitrous oxide and fentanyl were used. Blood samples (1-2 ml) for determination of methohexitone concentration in plasma were collected from a peripheral vein at $15,30,45$ and 120 minutes following administration of the rectal methohexitone. The samples were centrifuged and the plasma frozen for later assay using gas chromatography.

Following completion of surgery, anaesthesia was discontinued and the children were taken to the recovery room to awaken in the presence of their parents. Recovery time was noted and recovery assessed by a blinded observer using Steward's postanaesthesia recovery score ${ }^{12}$ which assigns points based upon the level of consciousness, the ability to maintain a patent airway and patient movement. The maximum score is six and indicates that the child is awake, capable of crying or coughing and moving purposefully. Scores for each patient were determined upon admission to the recovery room, at $5,15,30$ and 60 minutes following admission, and at the time the child was discharged from the recovery room.

Methohexitone concentrations were determined using the technique described by $V$ an Hamme and Ghoneim. ${ }^{13}$ After extraction of methohexitone from plasma samples with hexane, hexobarbitone was added as an intermal control and separation of the sample performed on a Hewlett Packard 5830A gas chromatograph. The area of the curves was measured on a Hew lett Packard integrator and methohexitone concentrations calculated from a calibration graph derived from control plasma to which known amounts of drug had been added. Using this method of extraction the correlation coefficient of control plasma containing known amounts of methohexitone was linear for concentrations between $0.1-20 \mu \mathrm{g} \cdot \mathrm{ml}^{-1}$ ( $\mathrm{r}=$ 0.99 ). Sensitivity of the assay was $0.03 \mu \mathrm{g} \cdot \mathrm{ml}^{-1}$ and reproducibility of duplicate samples \pm 8 per cent.

Results are expressed as mean $\pm \mathrm{SD}$. Induction and recovery times and plasma methohexitone concentrations were analyzed using Student's t test with $p<0.05$ considered significant. The recovery room scores were analyzed using the Wilcoxon non-paired rank sum test.

\section{Results}

The two groups of children were comparable in age, weight, methohexitone dose administered and duration of surgery (Table). Following rectal administration of methohexitone, 26 of 30 patients fell asleep within 15 minutes. Four patients, although sedated, remained awake 20-30 minutes after receiving the drug and underwent inhalation induction of anaesthesia with halothane and nitrous oxide in oxygen. Three of these patients received ten per cent methohexitone; one received the two per cent solution.

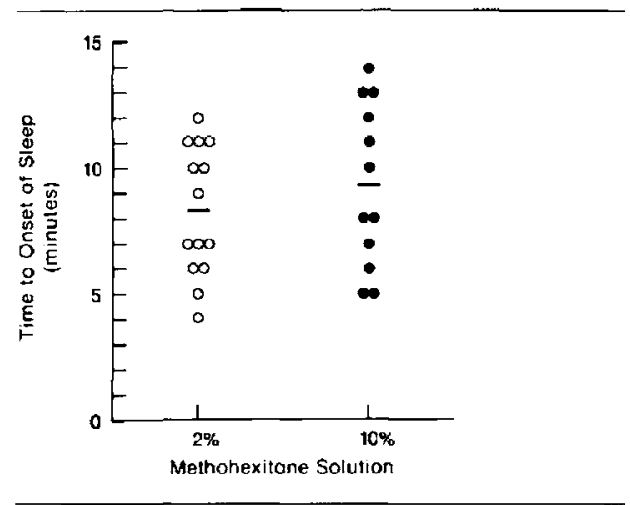

FIGURE 1 Induction times following rectal administration of methohexitone $\left(25 \mathrm{mg} \cdot \mathrm{kg}^{-1}\right)$, as a two or ten per cent solution. Circles represent individual patients. (-) indicates mean induction time. Three patients in the ten per cent group and one patient in the two per cent group failed to fall asleep 20 -30 minutes after receiving the drug and are not included in the figure.

Time to the onset of sleep following administration of two per cent rectal methohexitone was $8.3 \pm 2.6$ minutes (range 4-12 minutes). Following ten per cent methohexitone, sleep was achieved in $9.3 \pm 3.3$ minutes (range 5-14 minutes). The difference was not significant (Figure 1).

The plasma methohexitone concentrations at 15,30 and 45 minutes were significantly higher following administration of the two per cent solution (Figure 2). In the four patients that did not fall asleep the 15-minute plasma samples were not obtained. Initial samples from these patients were collected 21-30 minutes after administration of the rectal methohexitone and following induction of anaesthesia with halothane, nitrous oxide and oxygen. Peak plasma concentrations in these four patients ranged from $0.31-1.71 \mu \mathrm{g} \cdot \mathrm{ml}^{-1}$ immediately after the induction of anaesthesia.

Postanaesthesia recovery was similar in the two groups. Time from discontinuing anaesthesia until discharge from the recovery room was $88 \pm 27$ minutes and

TABLE Patient characteristics (mean $\pm S D$; range in parentheses)

\begin{tabular}{|c|c|c|}
\hline & $2 \%$ Methohexitone & 10\% Methohexitone \\
\hline Age (months) & $39.7 \pm 19.3(12-71)$ & $35.5 \pm 18.1(13-63)$ \\
\hline \multicolumn{3}{|l|}{ Sex } \\
\hline Make & 7 & 8 \\
\hline Female & 8 & 7 \\
\hline Weight (kg) & $15.8 \pm 4.7(10.7-25.2)$ & $14.4 \pm 3.9(9.1-21.0)$ \\
\hline $\begin{array}{l}\text { Methohexilone } \\
\text { dose (mg) }\end{array}$ & $394 \pm 118(270-630)$ & $359 \pm 96(225-525)$ \\
\hline Surgery timc & & \\
\hline$(\min )$ & $144 \pm 49(54-260)$ & $121 \pm 57(44-288)$ \\
\hline
\end{tabular}




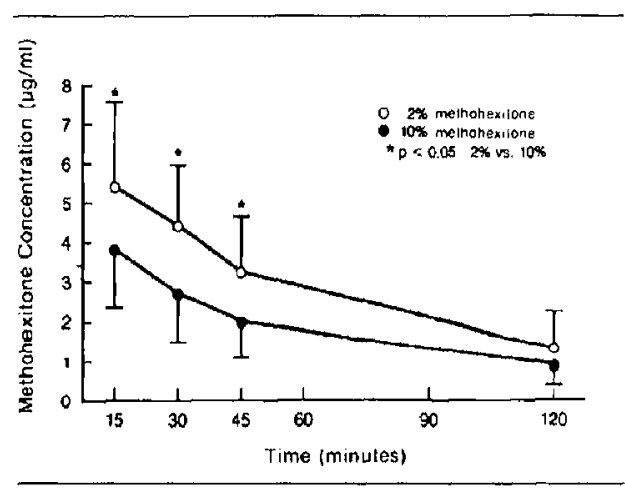

FIGURE 2 Plasma methohexitone concentrations following rectal administration of methohexitone ( $25 \mathrm{mg} \cdot \mathrm{kg}^{-1}$ ), as a two per cent or ten per cent solution (mean $\pm S D$ ).

$95 \pm 35$ minutes for the two and ten per cent methohexitone groups, respectively. The difference was not significant nor were the postanesthesia recovery scores significantly diffenent following surgical procedures of one to four hours duration under halothane and nitrous oxide anaesthesia (Figure 3).

In addition to the four paticnts that did not fall asleep one patient in each group developed hiccoughs during induction. Airway obstruction occurred in two patients that received the two per cent methohexitone solution. In both cases the obstruction was easily relieved by manual support of the airway. Three children from each group exhibited soiling following administration of methohexitone. Two of these three children from each group fell asleep, despite expelling a portion of the administered dose. There were no postoperative complications in either group.

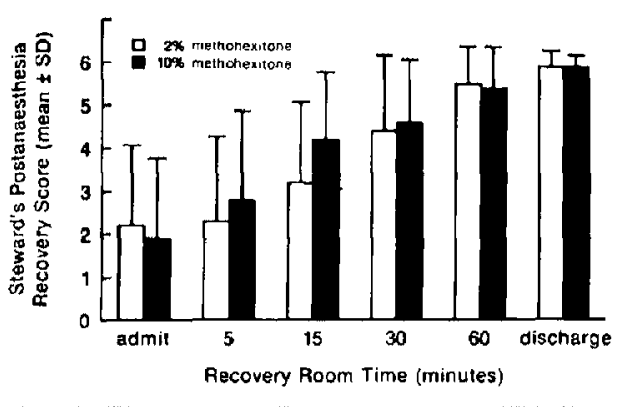

FIGURE 3 Steward's post anaesthesia recovery scores. Points are assigned for level of consciousness (awake -2 , responding - 1); airway (coughing or crying -2 , maintaining airway - 1); and patient movement (purposeful -2 , nonpurposeful - 1). Maximum score is $\operatorname{six} .^{12}$

\section{Discussion}

Both two and ten per cent solutions of rectal methohexitone provided adequate basal narcosis in this study. Previous investigators ${ }^{4-6}$ have reported that $84-92$ per cent of patients receiving $25 \mathrm{mg} \cdot \mathrm{kg}^{-1}$ of ten per cent methohexitone will fall asleep within 15 minutes. Our results agree with these earlier reports. Despite having had no preoperative sedation, 93 per cent of the children that received two per cent methohexitone were asleep within 12 minutes. When the ten per cent solution was used, sleep was successfully induced in 80 per cent of children. Patients were allowed 20-30 minutes to fall asleep, but none lost consciousness more than 14 minutes after administration of rectal methohexitone.

The onset of sleep was determined by a non-blinded observer and the possibility of observer bias cannot be excluded. However, Liu et al. reported that peak plasma methohexitone concentrations occur $14.9 \pm 2.0$ minutes following administration of the drug and suggested that a patient is likely to fall asleep, if the peak plasma methohexitone concentration exceeds $2 \mu \mathrm{g} \cdot \mathrm{ml}^{-1} .^{5}$ In this study plasma methohexitone concentrations at 15 minutes in 25 of the 26 patients that fell asleep exceeded $2 \mu \mathrm{g} \cdot \mathrm{ml}^{-1}$. Despite use of a non-blinded observer, the clinical findings were consistent with the changes that occurred in plasma methohexitone concentration and with the reports of other investigators. ${ }^{3-6,9}$ Because both solutions resulted in mean plasma methohexitone concen trations exceeding $2 \mu \mathrm{g} \cdot \mathrm{ml}^{-1} 15$ minutes following drug administration, it is not unexpected that the speed and reliability of induction would be similar for the two solutions. In the four patients who did not lose consciousness methohexitone concentrations remained below $2 \mu \mathrm{g} \cdot \mathrm{ml}^{-1}$.

Many factors affect the absorption and bioavailability of rectally administered medication. Because the rectal mucosa consists of a single layer of epithelial cells and does not have villi, the total area for drug absorption is relatively small. Also, venous drainage of the rectum is complex and the site of absorption affects the plasma concentration achieved. Methohexitone absorbed in the upper rectum enters the superior rectal vein and drains through the portal venous system into the liver. In contrast, methohexitone absorbed into the inferior and middle rectal veins enters directly into the systemic circulation. This suggests that first pass hepatic elimination of the drug ${ }^{14,15}$ may be avoided, if it is absorbed in the lower rectum.

Depositing and retaining methohexitone in the lower rectum may be difficult. The wall of the Inwer rectum is sensitive to chemical stimulation, also to tonicity and $\mathrm{pH}$, and the defecation reflex is easily stimulated. In addition, muscular activity due to constriction of the anal sphincter may push fluid into the upper rectum. ${ }^{16}$ It has also been 
suggested that use of a larger volume of a more dilute methohexitone solution will act as an cnema and initiate the defecation reflex, resulting in a higher incidence of soiling. ${ }^{17,18}$ Our study does not support this contention. Finally, body position, depth of catheter insertion and the presence of faeces in the rectum may influence the distribution and absorption of methohexitonc, although the effect of these factors has not been evaluated. Because of the complex relationship of the elements determining absorption of rectally administered medication, it may be difficult to predict the rate and cxtent of methohexitone absorption in an individual patient.

Rectal barbiturates can cause pain in humans ${ }^{1}$ and damage to the rectal mucosa in mice. ${ }^{10,11}$ Hinkle and Weinlander state that the severity of tissue damage scen following rectal methohexitone increased in proportion to the drig-musosa contact time and the concentration of the methohexitone solution administered. ${ }^{11}$ Their findings are consistent with reports of tissue damage following the inadvertent perivascular or intra-arterial injection of other concentrated barbiturate solutions. ${ }^{19,20}$ Use of a dilute methohexitone solution may minimize the risk of rectal mucosa damage.

In conclusion, we hypothesize that higher plasma levels of methohexitone following the use of the two per cent solution occur because a larger area of rectal mucosa is exposed to the drug, resulting in greater bioavailability. Although both two per cent and ten per cent methohexitone were effective for the induction of anaesthesia, the two per cent solution produced significantly higher plasma methohexitone concentrations. There was no difference in the speed or reliability of induction, the incidence of side effects or the postoperative recovery between the two groups. Further investigation will be required to determine the optimal dose and concentration. of rectal methohexitone for the induction of anaesthesia in children.

\section{Acknowledgements}

The authors gratefully acknowledge Geoff Johnson for his expert technical assistance and Sara Paul for preparation of the manuscript.

\section{References}

I Orallo $M O$, Eather $K F$. Sodium methohexital as a rectal agent in pediatric anesthesia. Anesth Aralg 1965; 44: 97-103.

2 Budd DC, Dornette WHL, Wright JF. Methohexital for rectal basal narcosis. Anesth Analg 1965; 44: 222-5.

3 Goresky GV, Steward DJ. Rectal methohexitone for induction of anaesthesia in children. Can Anaesth Soc J 1979; 26: 213-5.
4 Liu LMP, Goudsouzian NG, Liu PL. Rectal methohexital premedication in children, a dose-comparison study Anesthesiology 1980; 53: 343-5.

5 Lit LMP. Gaudreaut P, Friedman PA, Goudsouzian NG, Liu PL. Methohexital plasma concentrations in children following rectal administration. Anesthesiology 1985; 62: 567-70.

6 Quaynor $H$, Corbey $M$, Björkman $S$. Rectal induction of anaesthesia in children with methohexitone. $\mathrm{Br} J$ Anaesth 1985; 57: 573-7.

7 De Boer AG, Moolenaar F, de Leede LGJ, Breimer $D D$. Rectal drug administration: clinical pharmacokinetic considerations. Clin Phamacokinet 1982; $7: 285-311$.

8 De Boer AG, de Leede LGJ, Breimer DD. Drug absorption by the sublingual and rectal routes. $\mathrm{Br} J$ Anaesth 1984; 56: 69-82

9 Laishiey RS, O'Callaghan AC, Lerman J. Effects of dose and concentration of rectal methohexitone for induction of anaesthesia in children. Can Anaesth Soc J 1986; 33 : 427-32.

10 Hinkle AJ, Weinlander CM. Rectal mucosal injury after rectal premedication with methohexital (Abstract). Anesthesiology 1984; 61: A436.

11 Hinkle A.J, Weinlonder $C M$. The rectal toxicology of $10 \%$ methohexital: gross and histological effects in an animal model (Abstract). Anesthesiology 1985; 63: A461.

12 Steward DJ. A simplified scoring system for the postoperative recovery room. Can Anaesth Soc J 1975; 22: 111-3.

13 Van Hamme MJ, Ghoneim MM. A scnsitive gas chromatograph assay for thiopentone in plasma. Br J Anaesth 1978; 50: 143-5.

14 Hudson RJ, Stanski DR, Burch PG. Pharmacokinetics of methohexital and thiopental in surgical patients. Anesthesiology 1983; 59: 215-9.

15 Breimer DD. Pharmacokinetics of methohexitone following intravenous infusion in humans. $\mathrm{Br} J$ Anaesth 1976; 48: $643-9$

16 Boréus LO. Principles of Pediatric Pharmacology. New York: Churchill Livingstone, 1982, pp. 31-5.

17 Gregory GA. Pediatric Anesthesia. New York: Churchill Livingstone, 1983, pp. 444.

18 Berry FA. General philosophy of patient preparation, premedication, and induction of anesthesia; and inhalation anesthetic agents. I $n$ : Anesthetic Management of Difficult and Routine Pediatric Paticnts. Berry FA (Ed). New York: Churchill Livingstone, 1986, 31 .

19 Sione $H H$, Donnelly $C C$. The accidental intra-arterial in jection of thiopental. Anesthesiology 1961; 22: 9951006.

20 Forrester $A C$, Saunders RCO. Intra-arterial thiopentone. Br J Anaesth 1955; 27: 594-6. 


\section{Résumé}

Les concentrations plasmatiques de méthohexitone ont été déterminées chez 30 enfants âgés de un à six ans ayant rȩ̧u 25 $\mathrm{mg} \cdot \mathrm{kg}^{-1}$ de méthohexitone par voie rectale soit en solution de deux ou de dix pour cent pour l'induction de l'anesthésie. Les échantillons veineux sanguins on été obtenus en $15,30,45$ et 120 minutes après l'administration du médicament. Vingt-six des 30 enfants furent endormis en dedans de quinze minutes. Les concentrations plasmatiques moyennes de méthohexitone étaient de $5.39,4.42,3.40 \mathrm{et} 1.54 \mathrm{mg} \cdot \mathrm{mi}^{-1} \dot{a} 15,30,45$ et 120 minutes après l'administration de deux pour cent de méthohexitoné. L'uilisation d'une solution de méthohexitone à dix pour cent a amené des concentrations moyennes plasmatiques de méthohexitone de 3.80 a 3.12. 2.31 et $1.07 \mathrm{mg} \cdot \mathrm{ml}^{-1}$ aux mêmes intervalles. Les concentrations plasmatiques de méthohexitone Étaient significativement suptrieures 15,30 et 45 minutes après l'administration de deux pour cent de méthofexitone compara. tivement a la solution de dix pour cent. 